\title{
The Effect of Different Processing Techniques in Sweet Potato (Ipomoea batatas) of Content Nutrition
}

${\text { Dyah } \text { Triasih }^{1 *} \text { and Fitri Dwi Utami }}^{2}$

\author{
${ }^{1}$ Study Program of Livestock Product Processing Technology State Polytechnic of Banyuwangi \\ ${ }^{2}$ Department of Biology Education, Universitas Sebelas Maret, Indonesia
}

\begin{abstract}
The objective of this study is to define the quality of sweet potato nutrition content in different processing techniques. Processing techniques were roasted, steamed, fried, and boiled. The research method was to experiment complete randomized design with four treatments and five replications for each treatment. The variables chemical quality test were water content, fat content, protein content, ash content, carbohydrate content, and total energy. The result of the chemical quality test showed processing techniques of sweet potato were significant influence water content, fat content, protein content, carbohydrate content, and analysis of total energy $(\mathrm{P}<0,05)$. The conclusion roasted processing techniques have higher levels of protein, carbohydrate content, and overall energy than others but have low on fat content, water content, and ash content.
\end{abstract}

Keywords: Chemical content, Processing techniques, Sweet potato

\section{INTRODUCTION}

Sweet potato is an alternative carbohydrate source instead of rice. Sweetpotato plants are relatively easy to cultivate because they have high adaptability to drought. Also, the nutrients contained in sweet potatoes can compensate for the nutrients found in wheat and rice. However, the demand and utilization of sweet potato in Indonesia are still quite low. Sweet potatoes were used as the staple food of the Papuan people and some regions in Eastern Indonesia. The utilization of sweet potatoes that have not been optimal is due to the lack of postharvest processing technology applied and the low economic value of sweet potato. The processing of sweet potato in Indonesia is still in the form of fresh sweet potatoes such as baked, broiled, and crisp fried

Sweet potatoes have physical properties such as shape, skin color, and meat and textures that vary according to variety (Rodriques et al., 2006). The shape and size of tubers are quality criteria that directly affect prices. The form of oval and not many bumps will facilitate the stripping process. Medium bulbs with a weight of 200-250 grams and uniforms require relatively fast stripping time compared to small or provide power for 123 calories. Sweet potatoes, in addition to providing high energy, mostly in the form of carbohydrates, also have high carotene, ascorbic acid, niacin, riboflavin, thiamin, and mineral contents (Ambarsari et al., 2009).

According to the Departemen Kesehatan (1981), sweet potatoes containing carbohydrates reached $27.9 \%$ with a water content of $68.5 \%$ and carbohydrate content in the form of sweet potatoes increases to $85.26 \%$ with an ash content of $7.0 \%$. Meanwhile, according to Zuraida and Supriati (2008), that sweet flour has higher ash content and fiber content with carbohydrate and calorie content equivalent to wheat flour. The complete nutritional content of sweet potato is suitable as a natural food ingredient that can improve health (Kolter et al., 2007).

Orange sweet potato processing process causes changes in the rate of decrease in betacarotene in the cooking time for 15 minutes, using the frying method down to $0.26 \%$ and the steaming method down to $0.24 \%$ (Purwanti, 2019). In addition, the processing of sweet potatoes causes a decrease in the chemical composition and nutrients of these foodstuffs such as water content, ash content, protein content and fat content (Hardoko, 2010)

Sweet potatoes processing can affect the content nutritional content, food safety, and consumer acceptance. Changes in nutrient content can result in changes in the chemical properties changes in color, texture, odor, and taste of sweet potatoes that is less or not preferred. This research was conducted to determine the effect of nutrient content including water content, ash content, fat content, protein content, carbohydrate content and total energy sweet potato to the cooking process by roasting, boiling, steaming, and frying.

\section{MATERIALS AND METHODS}

The tools used in this study were thermometers, analytical scales (analytical balance) with accuracy of $0.1 \mathrm{mg}$, porcelain plates (crucial), ovens with temperature that can be controlled, desiccators (water content analysis); muffle furnaces with controlled temperatures, Crucible silica with lid, spatula (ash content analysis); test tube, erlenmeyer glass, tube, and soxhlet reagent, $200 \mathrm{ml}$ fat flask, measuring pipette, titration instrument, heater, filter paper, beker glass (fat content analysis); macro kjeldahl heater, $500 \mathrm{ml}$ kjeldahl flask, distillation apparatus with straight 
conveyor kjeldahl tube adapters, distillation, burettes (protein content analysis); $400 \mathrm{ml}$ beaker cups, watch glasses, measuring cups, measuring flasks, blenders, cooking pans, pans, gas stoves, sample plastic bags, label paper, and scales.

The material that will be used in this research is sweet potatoes. The chemicals used for protein content analysis are sulfuric acid $98 \%$, the catalyst for mercury tablets, $\mathrm{BDH}$ or $\mathrm{Na} 2 \mathrm{SO} 4$ and 0.1 gram of mercury (kjeldahl tablets), $60 \% \mathrm{NaOH}$ solution, indicator methyl red and methyl blue ratio 2: $1, \mathrm{HCl}$ solution $0.1 \mathrm{~N}$, boric acid $0.3 \%$ whereas chemicals for analysis of fat content are 8 $\mathrm{N} \mathrm{HCl}$ solution (65\%), Diethyl ether (grade AR) or Petroleum ether (grade AR), aqua dest, and cooking oil 3 liters.

Sweet potato (not damaged) cleaned and peeled skin in a container filled with water so that no browning reaction (browning) and washed again clean. Next, sweet potatoes are cut using a knife, with a size of $4 \mathrm{~cm} \mathrm{x} 4 \mathrm{~cm}$ (cuboid or box). Baked sweet potatoes as much as $500 \mathrm{~g}$ in the oven with a temperature of $100^{\circ} \mathrm{C}$, for each roasting takes 15 minutes. Sweet potatoes that have been cooked are removed (drained) until cool. After the roasting process is complete, sweet potatoes are ready for chemical testing including water content, protein content, ash content, fat content, carbohydrate content, and total energy.

Sweet potato (not damaged) is cleaned and peeled in a container filled with water, so there is no browning reaction. Sweet potatoes are washed again clean. Next, the sweet potato is cut using a knife, with a size of $4 \mathrm{~cm} \times 4 \mathrm{~cm}$ (in the shape of a cube or a box). After being cut into small pieces, orange sweet potato is drained using a slicer of 500 grams of orange sweet potato steamed in a steaming pot with a temperature of $100^{\circ} \mathrm{C}$, for each steaming takes time 15 minutes. Cooked sweet potatoes are removed (drained) until cool. After the steaming process is complete, sweet potatoes are ready for chemical testing including water content, protein content, ash content, fat content, carbohydrate content, and total energy.

Sweet potato (not damaged) is cleaned and peeled the skin in a container filled with water so that no browning reaction (browning) and washed again clean Next, sweet potatoes are cut using a knife, with a size of $4 \mathrm{~cm} \mathrm{x} 4 \mathrm{~cm}$ (cuboid or box) Sweet potatoes are fried as much as $500 \mathrm{~g}$ in a deep frying tool with a temperature of $100^{\circ} \mathrm{C}$, for each frying it takes 15 minutes. Sweet potatoes that have been cooked are removed (drained) until cool. After the frying process is complete, sweet potatoes are ready for chemical testing including water content, protein content, ash content, fat content, carbohydrate content, and total energy.

Sweet potato (not damaged) cleaned and peeled skin in a container filled with water so that no browning reaction (browning) and washed again clean Next, sweet potatoes are cut using a knife, with a size of $4 \mathrm{~cm} \mathrm{x} 4 \mathrm{~cm}$ (cuboid or box). Sweet potato boiled as much as $500 \mathrm{~g}$ in a pan by adding 1 liter of water at a temperature of $100^{\circ} \mathrm{C}$, for each boiling takes 15 minutes. Sweet potatoes that have been cooked are removed (drained) until cool. After the boiling process is complete, sweet potatoes are ready for chemical testing including water content, protein content, ash content, fat content, carbohydrate content, and total energy.

The study was conducted using a Completely Randomized Design (CRD) of directional patterns with four treatments; each treatment was repeated four times.

P1: Roasted of potato sweet

P2: Boiled of potato sweet

P3: Steamed of potato sweet

P4: Fried of potato sweet

Result data chemical quality tests were analyzed by using variance analysis (ANOVA). If significant, further Duncan Test will be performed.

\section{RESULT AND DISCUSSION}

The result variance analysis for chemical quality test showed that different processing techniques cooking of potatoes sweet significant effect for water content, fat content, protein content, carbohydrate content, and analysis of total energy $(\mathrm{P}<0,05)$ (Table 1).

Tabel 1. Chemical content various techniques processing of sweet potatoes

\begin{tabular}{|c|c|c|c|c|}
\hline \multirow{2}{*}{ Variable } & \multicolumn{4}{|c|}{ Processing techniques } \\
\hline & P1 & $\mathrm{P} 2$ & P3 & $\mathrm{P} 4$ \\
\hline $\begin{array}{l}\text { Water } \\
\text { content }(\%)\end{array}$ & $53,16^{\mathrm{a}}$ & $65,39^{b}$ & $64,44^{\mathrm{c}}$ & $55,17^{\mathrm{d}}$ \\
\hline $\begin{array}{l}\text { Ash } \\
\text { Content } \\
(\%)\end{array}$ & $0,72^{\mathrm{a}}$ & $0,85^{\mathrm{b}}$ & $0,87^{\mathrm{c}}$ & $1,17^{\mathrm{d}}$ \\
\hline $\begin{array}{l}\text { Fat content } \\
(\%)\end{array}$ & $0,23^{\mathrm{a}}$ & $0,13^{\mathrm{b}}$ & $3,21^{\mathrm{c}}$ & $0,20^{\mathrm{d}}$ \\
\hline $\begin{array}{l}\text { Protein } \\
\text { Content } \\
(\%)\end{array}$ & 2,05 & 1,20 & 1,75 & 1,37 \\
\hline $\begin{array}{l}\text { Carbohydra } \\
\text { te content } \\
(\%)\end{array}$ & $43,84^{\mathrm{a}}$ & $32,43^{\mathrm{b}}$ & $29,73^{\mathrm{c}}$ & $42,09^{\mathrm{d}}$ \\
\hline $\begin{array}{l}\text { Analysis } \\
\text { total } \\
\text { energy } \\
\text { (kkal) }\end{array}$ & $\begin{array}{c}185,6 \\
3^{\mathrm{a}}\end{array}$ & $\begin{array}{c}135,6 \\
9^{\mathrm{b}}\end{array}$ & $\begin{array}{c}154,8 \\
1^{\mathrm{c}}\end{array}$ & $\begin{array}{c}175,6 \\
4^{\mathrm{d}}\end{array}$ \\
\hline
\end{tabular}

a,b,c Different superscripts on the same showed significant $(\mathrm{P}<0,05)$.

P1: Roasted, P2: Boiled, P3: Steamed and P4: Fried

\subsection{Water content}

The techniques processing significantly affect the water content of frozen meat. The different test results showed significantly different 
mean $(\mathrm{P}<0,05)$ was steamed processing boiled higher than steamed, fried, and grilled. Boiled more upper than boiled, steamed, fried, and roasted because of the longer boiling process, so that evaporated water increases, but finally, the vapor is absorbed back into the sweet potatoes. The effect, water content of the sweet potatoes is getting high. Starch has a property of being able to bind water molecules through hydrogen, thereby reducing the amount of free water in the ingredients (Kusumawati, 2013).

\subsection{Ash Content}

The various techniques of processing had a significant effect on the protein content of sweet potatoes $(\mathrm{P}<0,05)$. Frying method has a high ash content value from other methods. Ash content is used to detect mineral content found in food ingredients, whether from food ingredients or process machines. Very high ash levels indicate that there has been material contamination by the tool due to friction during the process. High and low values of ash content in fried foods depend on the time and temperature of the frying pan. The increase in ash content in fried food is thought to be caused by high temperatures so that a lot of water content is lost (Sundari, 2015).

\subsection{Fat Content}

The various techniques of processing had a significant effect $(\mathrm{P}<0,05)$ in the sweet potatoes. The steamed method has a higher fat content compared to other methods. This was because when steam is not much fat decomposes and fat is a minor component ranging from $0.29-2.7 \%$ (dry basis). The primary fatty acids are linoleic, linolenic, palmitic, and stearic. While lipids consist of 3 fractions, namely non-phospholipid, sepals, and lecithin. The level of damage fat varies greatly depending on the temperature used and the amount of processing time processing. The higher the temperature used, the more intense the damage to fat ( Sekar and Syarifa, 2008).

\subsection{Protein content}

The various techniques of processing had a significant effect on the protein content of sweet potatoes $(\mathrm{P}<0,05)$. The roasted method has a higher protein content compared to the other purpose. This is because the temperature method used is still relatively low compared to other purposes as a result of which proteins do not experience denaturation. The sweet potato protein content is around 1.3-10\% (\% dry weight). Most sweet potatoes only provide a small number of essential amino acids. Sweet potato protein is called ipomoea, which, during storage, is converted into polypeptides that have different physical and chemical properties. Boiling can reduce levels of protein in food; this is because processing using high temperatures will cause protein denaturation, so coagulation occurs and decreases solubility or solubility (Winarso, 2003).

\subsection{Carbohydrate content}

The various techniques of processing had a significant effect on carbohydrate content $(\mathrm{P}<0,05)$. The roasted method has a higher carbohydrate compared to the other methods. During cooking sweet potatoes or as long as sweet potatoes are roasted, some of the starch is converted into sugar, namely maltose and dextrose. The sucrose content does not change as long as the sweet potatoes are baked. In addition to maltose and sucrose, other types of sugar found in cooked sweet potatoes are fructose, glucose, and raffinose. The presence of raffinose, although in small amounts, will cause symptoms of real flatulence, namely the occurrence of raffinose fermentation by bacteria in the large intestine to produce gas, especially $\mathrm{H}_{2}$ and $\mathrm{CO}_{2}$. The use of high temperatures can be damage carbohydrate molecules so that the nutritional value decreases; besides that, processing that involves heating, which is high in carbohydrates, especially sugar will experience caramelization (browning) nonenzymatic) which can also cause extensive damage (Syarfaini et al., 2017).

\subsection{Total Energy}

The various techniques of processing had a significant effect $(\mathrm{P}<0,05)$ in the sweet potatoes. The roast method has higher total energy compared to the other methods. Because total energy correlates with carbohydrates, the higher the value of carbohydrates, the higher the total energy. Carbohydrate levels influence the increase in overall energy. The higher the amount of glucose, resulting in increased total energy (Ashfiyah, 2019).

\section{CONCLUSION}

The difference in the processing of sweet potatoes when viewed from the chemical quality shows that the roast method has higher levels of protein, carbohydrates, higher total energy, boiled process has high water content, fried method has high ash content, and the steamed method has a high fat content. Changes in nutrient content of sweet potatoes depend on the temperature and time used.

\section{REFERENCE}

1. M.J. Rodriguez, K. Oses, Ziani, and J.I. Mate. Food Res. Int. 39: 840 - 846 (2006)

2. R. Rukmana. Budidaya Talas. (Penerbit Kanisius, Yogyakarta, 1998)

3. I. Ambarsari, Sarjana, and A. Catholic. Rekomendasi Dalam Penetapan Standar Mutu Tepung Ubi Jalar. (Balai Pengkajian 
Teknologi Pertanian, Jawa, Tengah, 2009)

4. Departemen Kesehatan. Daftar Komposisi Bahan Makanan. (Penerbit Bharata, Jakarta, 1981)

5. N. Zuraida danY. Supriati. Usahatani ubi jalar sebagai bahan pangan alternatif dan diversifikasi sumber karbohidrat biogen (2008)

6. Kotler, Philip, and K.L. Keller. Manajemen Pemasaran. (Penerbit PT Indeks, Jakarta, 2007)

7. R. Purwati, R. Fadilah, dan S. Yanto. Jurnal Pendidikan Teknologi Pertanian, 5: 91 - 103 (2019)

8. H.T. Handoko. Pengaruh jenis emulsifier terhadap karakteristik roti tawar (Skripsi Jurusan Teknologi Pangan, UPH, 2005)

9. D.A. Kusumawati. Jurnal Pangan dan
Agroindustri 1, 90- 100 (2013)

10. N. Sundari, Almasyhuri, and A. Lamid. Media Litbangkes 25(4): 235 - 242 (2015)

11. D.S. Sekar, dan A.K. Syarifa. Pengaruh lama pemasakan dan temperatur pemasakan kedelai terhadap proses ekstraksi protein kedelai untuk pembuatan tahu (Skripsi JTK, F. Teknik, UNDIP, 2009)

12. D. Winarso. Journal Indon. Trop. Anim. Agric, 28(3):119-29 (2009)

13. Syarfaini, M.F. Satrianegara, S. Alam, and Amriani. Health Science Journal, 9(2): 138 152 (2017)

14. Ashfiyah, V.N. Media Gizi Indonesia, 14(1): $75-86$ (2019) 